\title{
Liquid Hot Water Pretreatment and Enzymatic Hydrolysis as a Valorization Route of Italian Green Pepper Waste to Delivery Free Sugars
}

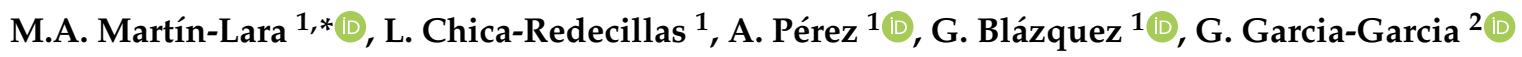 \\ and M. Calero ${ }^{1}$ \\ 1 Chemical Engineering Department, Faculty of Sciences, University of Granada, Avda. Fuentenueva, s/n, \\ 18071 Granada, Spain; luciachica@correo.ugr.es (L.C.-R.); aperezm@ugr.es (A.P.); gblazque@ugr.es (G.B.); \\ mcaleroh@ugr.es (M.C.) \\ 2 Department of Chemical and Biological Engineering, The University of Sheffield, \\ Sir Robert Hadfield Building, Sheffield S1 3JD, UK; G.Garcia-Garcia@sheffield.ac.uk \\ * Correspondence: marianml@ugr.es; Tel.: +34-958-240-445
}

Received: 4 September 2020; Accepted: 5 November 2020; Published: 10 November 2020

\begin{abstract}
In this work, liquid hot water pretreatment (autohydrolysis) was used to improve enzymatic hydrolysis of a commonly consumed vegetable waste in Spain, Italian green pepper, to finally produce fermentable sugars. Firstly, the effect of temperature and contact time on sugar recovery during pretreatment (in insoluble solid and liquid fraction) was studied in detail. Then, enzymatic hydrolysis using commercial cellulase was performed with the insoluble solid resulting from pretreatment. The objective was to compare results with and without pretreatment. The results showed that the pretreatment step was effective to facilitate the sugars release in enzymatic hydrolysis, increasing the global sugar yield. This was especially notable when pretreatment was carried out at $180{ }^{\circ} \mathrm{C}$ for $40 \mathrm{~min}$ for glucose yields. In these conditions a global glucose yield of $61.02 \%$ was obtained. In addition, very low concentrations of phenolic compounds (ranging from 69.12 to $82.24 \mathrm{mg} / \mathrm{L}$ ) were found in the liquid fraction from enzymatic hydrolysis, decreasing the possibility of fermentation inhibition produced by these components. Results showed that Italian green pepper is an interesting feedstock to obtain free sugars and prevent the enormous quantity of this food waste discarded annually.
\end{abstract}

Keywords: pretreatment; hydrolysis; Italian green pepper; liquid hot water; fermentable sugars; glucose; xylose; food waste

\section{Introduction}

About one-third of the total production of food in the world is wasted, amounting to 1300 million tons of food waste globally in 2011 [1]. In developing countries, food waste occurs mainly during cultivation, harvesting, transportation, and storage due to the use of inadequate and rudimentary techniques and technologies. On the contrary, in medium- and high-income countries food waste occurs mainly in the last stage of the food supply chain, i.e., households and food service establishments. Nevertheless, in medium- and high-income countries, cultivation, harvesting, and preserving techniques also produce significant losses of food, mainly due to strict quality regulations, such as limitations in size, shape, and color [1].

Fruits and fresh vegetables have one of the highest waste rates; approximately half of the total production of fruit and fresh vegetables is wasted [2,3]. Most of this waste is generated in Europe, since $49.4 \%$ of holdings that grow fresh vegetables that are consumed within in the European Union 
(EU) are located in Romania (22.1\%), Poland (15.4\%), and Spain (11.9\%) [4]. This EU report also indicated that almost 2.2 million hectares of land are used to produce vegetables for fresh consumption or further processing. About $17 \%$ of the $\mathrm{EU}$ lands used to produce fresh vegetables are located in Spain, which mainly produce the following vegetable crops: zucchini, cucumbers, eggplants, gherkins, melons, peppers, and tomatoes ( $27.6 \%$ of the Spanish produce) [4].

In this context, pepper (Capsicum annuum) is one of the most valuable vegetables [5]. Statista Research Department reported that about 36 million tons of peppers were produced in the world in 2018 [6]. China is the world's leading producer with around half of the peppers produced globally. Spain ranks fifth in the world's pepper production with 1.3 million tons [7]. With their 18,513 hectares of land for pepper production and a yield of $6.11 \mathrm{~kg} / \mathrm{m}^{2}$, Spain has the highest yield of the ten largest producers in the world [7-11]. Spain is also the largest European producer of pepper. The Netherlands is the second largest European producer, with a much lower production than Spain ( 0.34 million tons), followed by Italy [12]. Since the start of the pepper boom, between 40 to 45 years ago, Spanish production has continuously grown, with a current increase rate of around $5 \%$ every year [12].

Pepper waste represents a considerable percentage of the total vegetable waste generated in Spain [12]. Furthermore, due to its high content of carbohydrates (75.9\% in dry weight according to data from USDA), pepper waste has promising potential for the extraction of fermentable sugars. The potential production of bioethanol from these waste materials needs to be carried out by hydrolysis because some of the carbohydrates are in polymeric form (such as, cellulose and hemicellulose). The pretreatment of the pepper waste to facilitate the polysaccharides hydrolysis is a key step in the biotechnological procedure of pepper waste valorization [13].

Previous research has shown the performance of different biological, chemical, physical, and physicochemical pretreatments in order to transform the structure of cellulose, hemicellulose, and lignin and facilitate the depolymerization and liberation of fermentable sugars. For example, Cabrera et al. [14] explored alkaline and alkaline peroxide pretreatments at a mild temperature to enhance the enzymatic hydrolysis of rice hulls and straw. Hassan et al. [15] reviewed the pretreatment of lignocellulosic materials by emerging methods such as ultrasound and ionizing radiation. Intanakul et al. [16] revealed the advantages of microwave pretreatment to improve enzymatic hydrolysis of rice straw and sugarcane bagasse. Similarly, Loow et al. [17] revised the use of deep eutectic solvents and highlighted the advantage of using them as pretreatment agents of lignocellulosic materials. Sarkar et al. [18] and Sun and Cheng [19] summarized the main physical, chemical, physicochemical, and biological pretreatment techniques to facilitate the enzymatic attack in their review about available technologies for bioethanol production from lignocellulosic materials. Talebnia et al. [20] provided an overview of pretreatment technologies investigated for wheat straw before its transformation to bioethanol. The pretreatment technologies analyzed included physical (i.e., milling), physico-chemical (i.e., liquid hot water), chemical (i.e., dilute acids) and biological technologies (i.e., fungal treatments). Wan et al. [21] compared liquid hot water and alkaline pretreatment of soybean straw and showed that liquid hot water pretreatment was better than alkaline pretreatment. A combination of treatments has also been explored to see if a mixture of treatment can yield better results [22]. After this step, lignocelullosic materials became susceptible to hydrolysis and yields of monomeric sugars were increased [23]. The comprehensive overview of existing pretreatment technologies undertaken by Arshadi et al. [24], focused on wastes throughout the agri-food chain, was also of special interest. As a conclusion, the pretreatment is a key step in the processing of food waste. This process consists of the following steps: (1) pretreatment, (2) an enzymatic hydrolysis using commercial enzymes to release fermentable sugars, and (3) fermentation of the resulting sugar solution.

In studies focused on fresh vegetables, the hydrothermal pretreatment with dilute acids has been tested in more detail $[13,25,26]$. However, the development of greener pretreatments that avoid the use of chemicals is essential. In this context, novel high-pressure $\mathrm{CO}_{2}-\mathrm{H}_{2} \mathrm{O}$ processes, to produce oligosaccharides from the hemicellulose fraction and to enhance the cellulose digestibility for the 
enzymatic hydrolysis, is increasing the attention of researchers [27-30]. Another interesting green pretreatment is liquid hot water (autohydrolysis), commonly known as "green pretreatment process". It is a chemical-free procedure that does not require the addition of a catalyst. This pretreatment relies on pressure to maintain water in the liquid state at elevated temperatures [31-39]. Another benefit of the liquid hot water pretreatment (autohydrolysis) is that the formation of degradation products as phenolic compounds, furans, aliphatic carboxylic acids or uronic acids is low [40]. The disadvantage of this method, according to Manzanares et al. [36], is that liquid hot water pretreatment has high water and energy requirements. In any case, this pretreatment is receiving attention to be developed at the commercial scale.

Although optimization of liquid hot water pretreatment technology was previously reported in work by Wells et al. [41], the success of the "auto-hydrolysis process" depends mainly on crop type, harvest year, location, etc. and it needs to be carefully optimized for maximizing the final result. To the best of our knowledge, this pretreatment with hot water has scarcely been studied for green pepper. Only Díaz et al. [13] has published a study that describe the hydrolysis of supermarket vegetable wastes that included green pepper as substrate and some tests of the thermal hydrolysis performance.

In this context, the aims of the work presented in this article were as follows: (1) to investigate the efficiency of hydrothermal pretreatment as a technology for Italian green pepper waste pretreatment, (2) to optimize the pretreatment conditions in terms of temperature and operation time to maximize both hemicellulosic and cellulosic sugar recovery, and (3) to evaluate the enhancement of the sugar recovery as well as the minimization of inhibitors (phenolic compounds) in the liquid fraction of the enzymatic hydrolysis. This work supports the use of vegetable waste as raw materials to produce fermentable sugars.

\section{Materials and Methods}

\subsection{Raw Material: Italian Green Pepper Waste}

The Italian green pepper waste used in this study was collected from a greenhouse crop residues treatment plant. The industrial plant covers a space of more than 24 hectares, and is located at "Cortijo Galindo", in the municipality of Motril (Granada, Spain). It treats vegetable waste generated in the area, especially from intensive greenhouse agriculture. Peppers (Capsicum annuum L.) were selected as raw material of this study because they are one of the most important greenhouse crops produced in Granada. The material investigated in this work was the greenhouse crop residue from green peppers cultivation, which mainly contained the vegetable itself, but also prunings and other woody plants that could be present in greenhouse residues.

The material samples were firstly washed with distilled water, cut to a size of approximately $5 \mathrm{~mm}$ and then dried at $50{ }^{\circ} \mathrm{C}$. The resultant solid material was ground to a particle size lower than $2 \mathrm{~mm}$ to optimize surface area prior to pretreatment. Finally, the material was stored at $10^{\circ} \mathrm{C}$ until further use. The raw material mentioned below refers to the green pepper sample before pretreatment, denoted as RGP (raw green pepper).

\subsection{Characterization of Italian Green Pepper Residue Samples}

A structural analysis of the samples was performed by ASTM D1106-96:2013 method (lignin) [42], chlorination method (holocellulose) [43], ASTM D1103-60:1977 (cellulose) [44], and ASTM D1107-96:2013 (extractives) [45]. Hemicellulose content was calculated by subtracting the content of holocellulose from the content of cellulose. The carbohydrate, protein, and lipid contents were obtained from the food composition databases from the United States Department of Agriculture (USDA).

The total moisture content was determined by measuring the weight of the wet sample (as received) and the weight of the same sample after drying by air in a drying oven (Raypa, DOD50) at $50{ }^{\circ} \mathrm{C}$ until constant weight (approximately $72 \mathrm{~h}$ ). 
The proximate analysis was determined according to the following international standardized methods of analysis of solid biofuels of the International Organization for Standardization (ISO): ISO 18123:2015 (volatile matter) [46], ISO 18122:2015 (ash content) [47], and ISO 18134-1:2015 (equilibrium moisture content) [48]. Finally, fixed carbon content was calculated by difference (volatile matter, ash content, equilibrium moisture content, and fixed carbon must sum 100\%).

Determination of elemental composition (carbon, hydrogen, nitrogen, sulfur and oxygen concentrations) was performed using a Fisons, EA 1108 CHNS, elemental analyzer (Thermo Fisher Scientific, Madrid, Spain).

To experimentally determine the potential sugars, including glucose and xylose, $0.5 \mathrm{~g}$ of sample free of extracts and dried was introduced into an Erlenmeyer flask to which $5 \mathrm{~mL}$ of $72 \% \mathrm{H}_{2} \mathrm{SO}_{4}$ was added, and then kept in a water batch at $30^{\circ} \mathrm{C}$ for one hour making periodic agitations. Next, the solution was diluted by adding distilled water to reach $4 \% \mathrm{H}_{2} \mathrm{SO}_{4}$. Then, the dilute solution was then autoclaved at $121{ }^{\circ} \mathrm{C}$ for one hour. Finally, the solution was cooled down to room temperature, and filtered on a pore plate number 3 , obtaining a solid phase for quantification of the lignin and a liquid phase that was frozen until later analysis. Specifically, potential sugars were determined by high performance liquid chromatography (HPCL), according to analytical methods described in Section 2.5.

The bulk density of dried and milled sample was determined following standard EN 15103, using a standardized container.

Finally, infrared analysis was performed in the range of $4000-400 \mathrm{~cm}^{-1}$ using a Fourier transformed infrared spectrophotometer (FTIR), Perkin-Elmer, Spectrum-65 model (Perkin-Elmer, Madrid, Spain).

\subsection{Liquid Hot Water Pretreatment}

Experiments were performed with $50 \mathrm{~g}$ of green pepper samples that were mixed with $500 \mathrm{~mL}$ distilled water (weight/volume ratio of $10 \%$ ). The suspension was heated in a high pressure, bolted closure laboratory stirred reactor (ILSHIN) at 150,165 , and $180^{\circ} \mathrm{C}$ with pressure maintained at $4.8,7.5$, and 10.8 bar, respectively. After reaching the operating temperature, the suspension was held at a stable temperature for 10 and $40 \mathrm{~min}$. Then, the solids were separated with a sieve with a size of $125 \mu \mathrm{m}$ and the liquid phase was frozen at $-20^{\circ} \mathrm{C}$ until being analyzed. The insoluble solid (IS) residue was dried and stored at $10^{\circ} \mathrm{C}$ until further use.

The operating conditions were chosen according to recent published works on the use of liquid hot water techniques as pretreatment of lignocelullosic materials for the production of fermentable sugars [41,49].

\subsection{Enzymatic Hydrolysis (Saccharification Step)}

The protocol of the enzymatic hydrolysis was based on studies of Binod et al. [50], Larnaudie et al. [51] and Manzanares et al. [36]. Enzymatic hydrolysis was carried out in glass bottles of a total volumetric capacity of $100 \mathrm{~mL}$ by mixing $8 \mathrm{~g}$ of RGP or IS resulting from pretreatment with $80 \mathrm{~mL}$ of distilled water. Commercial enzyme from Trichoderma reesei, Celluclast ${ }^{\circledR} 1.5 \mathrm{~L}$ (aqueous solution, enzymatic activity $\geq 700$ Endoglucanase units $/ \mathrm{g}$, density $1.10-1.30 \mathrm{~g} / \mathrm{mL}$; provided by Sigma-Aldrich, (Madrid, Spain) was added to suspension in a charge of 15 units by gram of solid. For this operation, the $\mathrm{pH}$ was adjusted to 4.5 and the mixture was treated for $24 \mathrm{~h}$ at $50{ }^{\circ} \mathrm{C}$ (optimal temperature for celluclast) at a stirring rate of $300 \mathrm{rpm}$. Afterwards, the bottles were treated to $95^{\circ} \mathrm{C}$ for $5 \mathrm{~min}$ in order to stop the enzymatic reaction. Finally, samples were sieved, centrifuged and filtrated to separate solid and liquid fractions. The liquid fraction was frozen at $-20{ }^{\circ} \mathrm{C}$ until being analyzed.

\subsection{Analytical Methods}

The total phenols of the liquid fractions obtained from the enzymatic hydrolysis were measured using the Folin-Ciocalteu method, as reported by Greenberg et al. [52], with gallic acid as reference substance. Folin-Cicolteau, sodium carbonate, and gallic acid reagents were provided by Sigma-Aldrich. After the method was applied, a reaction based on electron transfer was produced and a blue color, 
proportional to the number of hydroxyl groups, was formed in samples. Then, samples were measured at $765 \mathrm{~nm}$ in a UV-visible spectrophotometer (Thermo Spectronic, Genesys 6, Madrid, Spain).

The glucose and xylose contents of all the liquid fractions were determined using high performance liquid chromatography (HPLC). Among the multiple types of HPLC that exist, we chose ion chromatography because of its widespread use to separate monosaccharides. Particularly, the 940 Professional IC Vario equipment (Methrohm, Herisau, Switzerland) was used. Glucose and xylose were used as monosaccharide standards. A column MetrosepCarb 2 250/4.0 was used under the following conditions: mobile phase, $100 \mathrm{mM} \mathrm{NaOH}$ and $10 \mathrm{mM} \mathrm{NaAc}$; flow rate, $0.5 \mathrm{~mL} / \mathrm{s}$; column temperature, $303 \mathrm{~K}$, which were the same operating conditions as those reported in our previous work [53].

\subsection{Parameters Definition}

In order to evaluate the effects of different pretreatment conditions, a series of parameters was used that referred to the changes in the raw material as a result of the pretreatment. Equations for the determination of these parameters are described below. Solid materials in the different equations are considered on a dried basis as follows.

- $\quad$ Solid yield (SY, \%)

This parameter gives information about the amount of raw material solubilized as a consequence of the effect of the pretreatment. It is defined as the amount of solid material obtained after the pretreatment stage (insoluble solid (IS) or pretreated material), in relation to the amount of raw material introduced (raw green pepper (RGP)), using Equation (1):

$$
\mathrm{SY}, \%=\frac{\mathrm{g} \text { of IS }}{\mathrm{g} \text { of RGP }} \times 100
$$

- Component concentration in the pretreated material

The concentration of each component (glucose and xylose) in the pretreated material is calculated based on the amount of this component in the pretreated material referred to as the dry weight of the pretreated material:

$$
\text { Component concentration, } \%=\frac{\mathrm{g} \text { of component in IS }}{100 \mathrm{~g} \text { of IS }}
$$

- Recovery of components after pretreatment

This variable refers to the amount of each component in the fraction considered (insoluble solid (IS) or liquid fraction (LF)) based on its content in the raw material. It provides information on the recovery of each component after the pretreatment stage:

$$
\begin{aligned}
& \text { Component recovery IS, } \%=\frac{\mathrm{g} \text { of component in IS by gram of IS }}{\mathrm{g} \text { of component in RGP by gram of RGP }} \times \mathrm{SY} \\
& \text { Component recovery LF, } \% \\
& \qquad=\frac{\mathrm{g} \text { of component in LF from pre-treatment }}{\mathrm{g} \text { of component in the amount of RGP used in pre-treatment }} \times 100
\end{aligned}
$$

- $\quad$ Saccharification efficiency (SE, \%)

This parameter shows the amount of component released during the enzymatic hydrolysis (EH) step, in relation to the amount of potential component in the pretreated material or in the raw material. 
It provides information about the susceptibility of the IS to the enzymatic attack result, and as such, it is an important variable to measure the effectiveness of the pretreatment:

$$
\mathrm{SE}, \%=\frac{\mathrm{g} \text { of component in LF from } \mathrm{EH}}{\mathrm{g} \text { of component in the amount of IS used in } \mathrm{EH}} \times 100
$$

- Global efficiency (GE, \%)

This variable refers to the amount of component in the raw material capable of being fermented after the stages of pretreatment and enzymatic hydrolysis. It is calculated as the summation of the component content in the liquid fraction (LF) and the one generated in the $\mathrm{EH}$, referring to the content of component in the raw material:

$$
\mathrm{GE}, \%=\frac{\frac{\mathrm{g} \text { of component in LF from EH }}{\mathrm{g} \text { of IS }} \times \frac{\mathrm{SY}}{100}+\frac{\mathrm{g} \text { of component in LF from Pre-treatment }}{\mathrm{g} \text { of RGP }}}{\mathrm{g} \text { of component in RGP by gram of RGP }} \times 100
$$

\subsection{Statistical Analysis}

All measurements were undertaken at least in triplicate. Data are presented as means with error bar and \pm indicating standard deviations. Collected data were statistically analyzed using analysis of variance (ANOVA) and significant differences between means of data were compared. A post hoc analysis to determine which means are significantly different from which others was also implemented. Although there are several multiple comparison procedures, the Fisher's least significant difference (LSD) procedure was chosen in this work.

\section{Results and Discussion}

\subsection{Green Pepper Waste Characterization}

The raw material used in this research was characterized according to the methods of analysis described in Section 2.2. It is important to highlight that our sample is the greenhouse crop residue from green peppers cultivation, which mainly contains the vegetable itself, but also prunings and other woody plants that could be in greenhouse residues. The raw material had a moisture content of $95.6 \%$.

Table 1 shows the main composition of green pepper (\% dry basis). The values are an average of three repetitions, except data of carbohydrates content that were adapted from USDA. Carbohydrates make up approximately $75.9 \%$ of the initial dry material, which makes this residue a very suitable substrate for the production of ethanol [54]. Its degree of lignification is in the range of what is described for other similar vegetable waste such as eggplant $(7.47 \%)$ [55] or tomato $(5.85 \%)$ [56]. The high ash content of Italian green pepper $(7.0 \%)$ is also in agreement with results of other researchers. For example, a study about applications of pea peel found an ash content value for this solid of $5.65 \%$ [57]. Singh et al. [58] in their study about utilization of vegetable wastes for bioenergy generation also reported values between $6 \%$ and $12 \%$ for potato samples. However, other authors, such as Pinna-Hernández et al. [59], recently found higher ash content (13.6\%) for vegetable residues from greenhouse peppers. 
Table 1. Main composition of green pepper used as raw material in this work (data in $\mathrm{g}$ by $100 \mathrm{~g}$ of dry weight).

\begin{tabular}{ccc}
\hline & Analysis & Data \\
\hline & Carbohydrates (data adapted from USDA) & 75.9 \\
& Protein (data adapted from USDA) & 14.1 \\
Structural and nutritional analysis & Total lipid (data adapted from USDA) & 2.8 \\
& Lignin & $8.7 \pm 0.8$ \\
& Cellulose & $24.8 \pm 1.9$ \\
& Hemicellulose & $10.7 \pm 1.1$ \\
Proximate analysis & Extractives & $2.3 \pm 0.1$ \\
& Equilibrium moisture & $3.0 \pm 0.1$ \\
& Fixed carbon & $14.7 \pm 1.9$ \\
& Volatile matter & $75.3 \pm 3.6$ \\
& Ashes & $7.0 \pm 0.4$ \\
\hline Elemental analysis & Carbon, C\% & $43.9 \pm 1.2$ \\
& Nitrogen, N\% $\%$ & $3.2 \pm 0.2$ \\
& Hydrogen, H\% $\% .4 \pm 0.4$ \\
& Sulfur, S\% & $<0.1$ \\
& Oxygen, O $\%$ & $39.4 \pm 1.0$ \\
\hline Potential sugars & Glucose & $33.7 \pm 3.4$ \\
(experimental data) & Xylose & $11.4 \pm 0.7$ \\
& Fructose & $0.9 \pm 0.1$ \\
& Lactose & $3.4 \pm 0.4$ \\
& Sacarose & $1.1 \pm 0.3$ \\
\hline
\end{tabular}

With respect to elemental analysis, green pepper is mainly composed of carbon (43.9\%) and oxygen $(39.4 \%)$, with $6.4 \%$ of hydrogen, $3.2 \%$ of nitrogen, and practically no sulfur. According to our results, the sum of potential sugars reached approximately $50.5 \%$ of dry weight. This is in agreement with United Stated Department of Agriculture (USDA) data and with studies by Guil-Guerrero et al. [60] and Diaz et al. [13]. Regarding potential sugars, $66.7 \%$ of them were identified as glucose and $22.6 \%$ as xylose, while the sum of fructose, lactose, and saccharose represented only $10.7 \%$. If the results of cellulose content are compared to potential glucose data, it can be concluded that the material has moderate non-cellulosic sugar content. This glucose is more likely to be monomeric glucose.

Finally, bulk density is an important parameter because it allows estimating storage and transport space needs and affects the handling and processing systems [61]. The bulk density value obtained for dried and milled Italian pepper was $431 \mathrm{~kg} / \mathrm{m}^{3}$. This is a good value if it is compared with other feedstock materials such as those reported by Vasco-Correa and Shah [62]. It implies the need of equipment with less capacity to pretreat the same amount of material.

\subsection{Performance of Hydrothermal Pretreatment}

The evaluation of the performance of hydrothermal pretreatment was made analyzing the effect of temperature and contact time on the recovery of sugars in the solid and liquid fraction after pretreatment.

\subsubsection{Solid Yield}

The solid yields (SY, \%) for different temperatures and pretreatment times are shown in Figure 1. The values decreased from $53.9 \%$ to $46.6 \%$ as temperature and time increased, mainly due to the progressive solubilization of some components of the raw material such as hemicellulosic sugars, extractives, and soluble ashes. These are the compounds that are most easily solubilized in this type of hydrothermal pretreatment, since their structure is less complex than that of other components of the vegetable waste $[41,49,51,63-65]$. The decrease in the solid recovery was well in agreement with the 
literature $[35,66-69]$. Additionally, the low values (always lower than $55 \%$ ) may be explained by the easy solubilization and volatilization phenomena of certain compounds, as previously described by Mok and Antal [64].

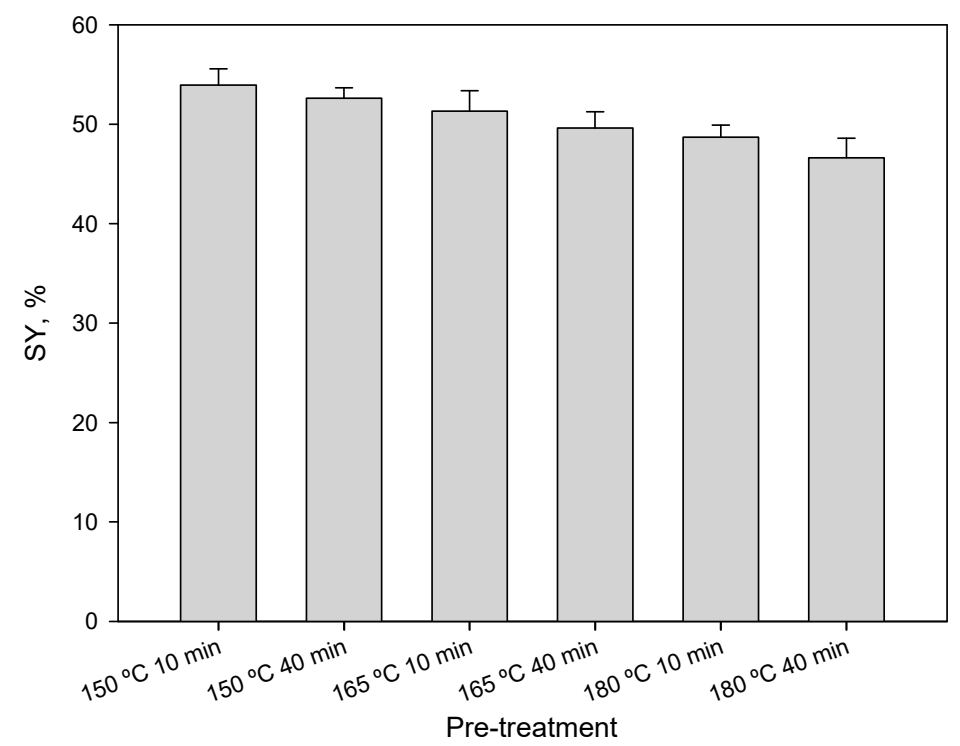

Figure 1. Solid yields (SY, \%) for each operating conditions of liquid hot water pretreatment.

\subsubsection{Recovery of Sugars}

The recovery of sugars in the pretreated material (insoluble solid) and liquid fraction at different pretreatment conditions are shown in Figure 2a,b, respectively. Data were calculated for total potential glucose and xylose derived from cellulose and hemicellulose. The results refer only to glucose and xylose because they were the main sugars detected. Values of over $86 \%$ recovery of glucose in the insoluble solid were obtained. These results seem to indicate that operating conditions analyzed could result in a certain solubilization of the cellulose of the raw material. According to the data obtained, an increase in temperature and time produced a negative effect on glucose recovery in the insoluble solid. Regarding the recovery of xylose in the insoluble solid, Figure 2a shows the obtained results. It can be observed that temperature and time both have a greater effect on its release from the raw material, decreasing its content in the insoluble solid as the severity of the pretreatment is increased. The values decreased from $95.3 \%$ at operating conditions of $150{ }^{\circ} \mathrm{C}$ and $10 \mathrm{~min}$ to the lowest value of $55.24 \%$ at severe operating conditions of $180^{\circ} \mathrm{C}$ and $40 \mathrm{~min}$.

Figure $2 \mathrm{~b}$ shows the sugar recovery values in the liquid fraction. Glucose released as a consequence of the hydrothermal pretreatment was lower than $14 \%$ in all the experimental conditions, showing an important effect of the increase in temperature and time. On the one hand, the fact of finding glucose in the liquid fraction, even under conditions of smoother pretreatments, suggests that glucose could come from another source more easily soluble than cellulose. On the other hand, glucose could constitute an important sugar of the hemicellulosic component and could be released from this component [70]. In addition, the fact that the values are different under diverse operating conditions supports this hypothesis. 
Temperature and time showed a stronger effect on the recovery values of xylose in the liquid fraction. At a high temperature $\left(180^{\circ} \mathrm{C}\right)$, the time increase from 10 to $40 \mathrm{~min}$ resulted in an increased xylose recovery from $25.42 \%$ to $44.76 \%$ (i.e., the maximum recovery value of xylose in the liquid fraction at the studied operating conditions). Similarly, when 40 min of operation time was chosen, a temperature increase from 150 to $180{ }^{\circ} \mathrm{C}$ caused an increase in the value of xylose recovery to $68.46 \%$. Results also showed that pretreatment at $150{ }^{\circ} \mathrm{C}$ and $165^{\circ} \mathrm{C}$ would require longer residence time (high than $40 \mathrm{~min}$ ) if recoveries of xylose higher than to $30 \%$ were being sought. It could be hypothesized that a pretreatment conducted at a temperature greater than $180{ }^{\circ} \mathrm{C}$ and with a residence time longer than $40 \mathrm{~min}$ could lead to a higher recovery of xylose. However, in this case, some additional experimentation would be performed in order to analyze the degradation of these sugars under severe operating conditions. It is important to highlight that it is impossible to have zero sugar degradation at the analyzed operating temperatures when sugar release comes from soluble sugars (glucose and xylose) [70-72]. Xylose is especially sensitive. Therefore, some soluble sugars may be "lost" during pretreatment.

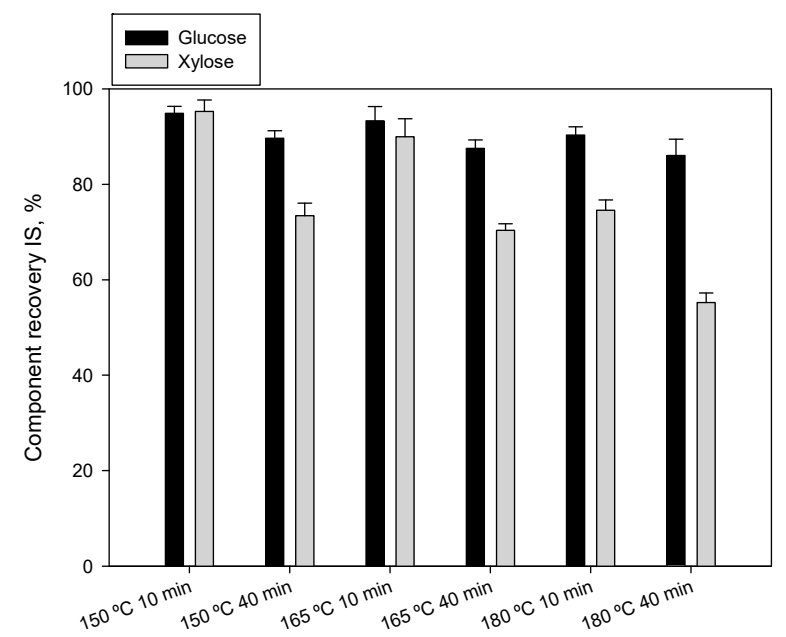

(a)

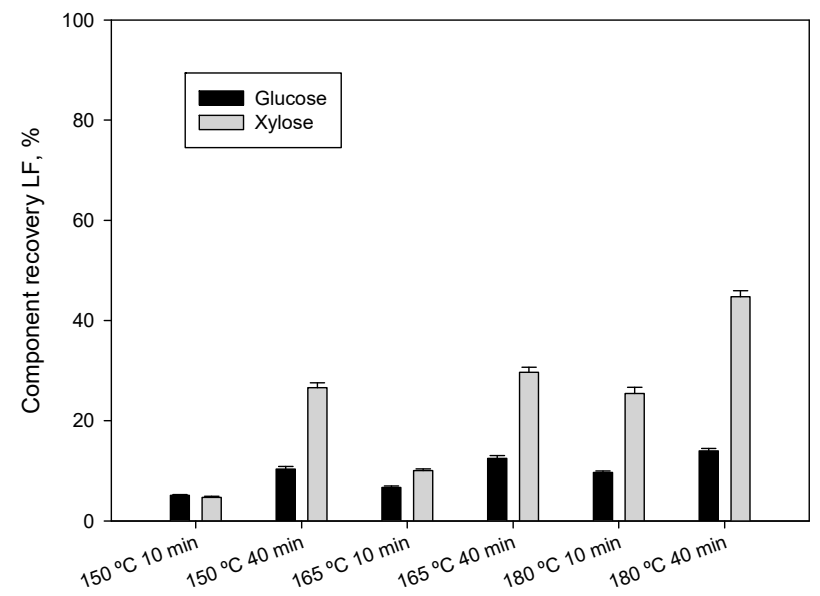

(b)

Figure 2. Sugar recovery for each operating conditions of liquid hot water pretreatment. (a) On insoluble solid (IS); (b) on liquid fraction (LF). Data were calculated for total potential glucose and xylose. 


\subsubsection{Content of Structural Components in Residual Solids}

With regard to structural components (cellulose, hemicellulose and lignin), the hydrothermal pretreatment using liquid hot water is capable of producing structural changes of the components of Italian green pepper waste. Without pretreatment, the green pepper waste is composed of $8.7 \%$ lignin, $24.8 \%$ cellulose and $10.7 \%$ hemicellulose, on a dry matter basis. Liquid hot water pretreatment resulted in a significant dissolution of hemicellulose. According to our results, hemicellulose was almost completely solubilized and deconstructed from biomass in hot water pretreatment at $180{ }^{\circ} \mathrm{C}$ for $40 \mathrm{~min}$. These results agreed with data reported by Nitsos et al. [73] in their study about optimization of hydrothermal pretreatment of hardwood and softwood lignocellulosic residues for selective hemicellulose recovery and improved cellulose enzymatic hydrolysis. Additionally, Gullón et al. [74] reported that hemicellulose was the easiest fraction to hydrolyze and that the acetic acids released from the hemicellulose acetyl group hydrolysis were those that catalyze the material pre-treatment. On the contrary, cellulose and lignin were mostly preserved in the solid residues after liquid hot water pretreatment. The content of cellulose increased from $24.8 \%$ to $26.5 \%$ (w/w, dry matter). This could corroborate that cellulose was not especially altered during liquid hot water pretreatment. This is the reason why the enzymatic hydrolysis assays were performed using a fixed amount of enzyme (cellulase) per unit of solid. The approximately constant cellulose content of the analyzed samples explains the results reported in Section 3.3. Finally, the lignin content was slightly increased from $8.7 \%(w / w$, dry matter) in the untreated Italian green pepper to about $10.1 \%(w / w$, dry matter) in the pretreated solids. Similar results about cellulose and lignin contents were reported by Li et al. [35], Manzanares et al. [36], and Tian et al. [38] in their studies about the effect of liquid hot water pretreatment on the chemical-structural alteration of poplar, olive oil pomace residue and rigid hardwood, respectively.

The Fourier transform infrared spectroscopy (FTIR) technique was used to elucidate structural changes on the material during liquid hot water pretreatment. Figure $3 a, b$ shows the infrared spectra of raw material and insoluble solid resulting from pretreatment at $180^{\circ} \mathrm{C}$ for $40 \mathrm{~min}$, respectively. The complexity and heterogeneity of materials were shown by the abundant and overlapped absorption bands. Representative bands/peaks found in spectrum of raw material were as follows [75,76]: $3286 \mathrm{~cm}^{-1}$ (O-H stretching), $2924 \mathrm{~cm}^{-1}$ (C-H stretching), $2858 \mathrm{~cm}^{-1}\left(-\mathrm{OCH}_{3}\right.$ methoxyl and $\mathrm{C}-\mathrm{H}$ stretching), $1740 \mathrm{~cm}^{-1}$ ( $\mathrm{C}=\mathrm{O}$ stretching), $1623 \mathrm{~cm}^{-1}$ ( $\mathrm{C}=\mathrm{C}$ benzene stretching ring and $\mathrm{C}=\mathrm{O}$ stretching conjugate with aromatic rings), $1371 \mathrm{~cm}^{-1}$ (symmetric C-H bending from methoxyl group), $1243 \mathrm{~cm}^{-1}$ (weak O-C stretching), and $1028 \mathrm{~cm}^{-1}$ (C-O ether vibrations and C-C ring vibrational stretching). After liquid hot water pretreatment, a decrease in absorbance was produced. An absorption peak at $1728 \mathrm{~cm}^{-1}$ attributed to $\mathrm{C}=\mathrm{O}$ vibration of acetyl or $\mathrm{COOH}$ groups was also significantly enhanced (in relation to the rest of peaks/bands). A major number of small peaks between 1728 and $1031 \mathrm{~cm}^{-1}$ were found (characteristic of pure lignin spectra). Of special relevance were the new peaks found at wavenumber of $1514 \mathrm{~cm}^{-1}$, characteristic of aromatic skeletal vibrations of lignin, and $1163 \mathrm{~cm}^{-1}$, attributed to C-O-C asymmetric valence vibration. Finally, the characteristic peak at $1371 \mathrm{~cm}^{-1}$ of symmetric $\mathrm{C}-\mathrm{H}$ bending from methoxyl group decreased as a consequence of the degradation of cellulose and hemicellulose. According to these results, a major proportion of lignin in the pretreated material seemed to be observed since lignin offered a characteristic peak at about $1514 \mathrm{~cm}^{-1}$, corresponding to the aromatic skeletal vibration, and a higher number of small peaks between 1750 and $1000 \mathrm{~cm}^{-1}$ approximately [73]. This observation could indicate that no depolymerization of lignin during the pretreatment occurred, as already suggested by Ázar et al. [77]. 


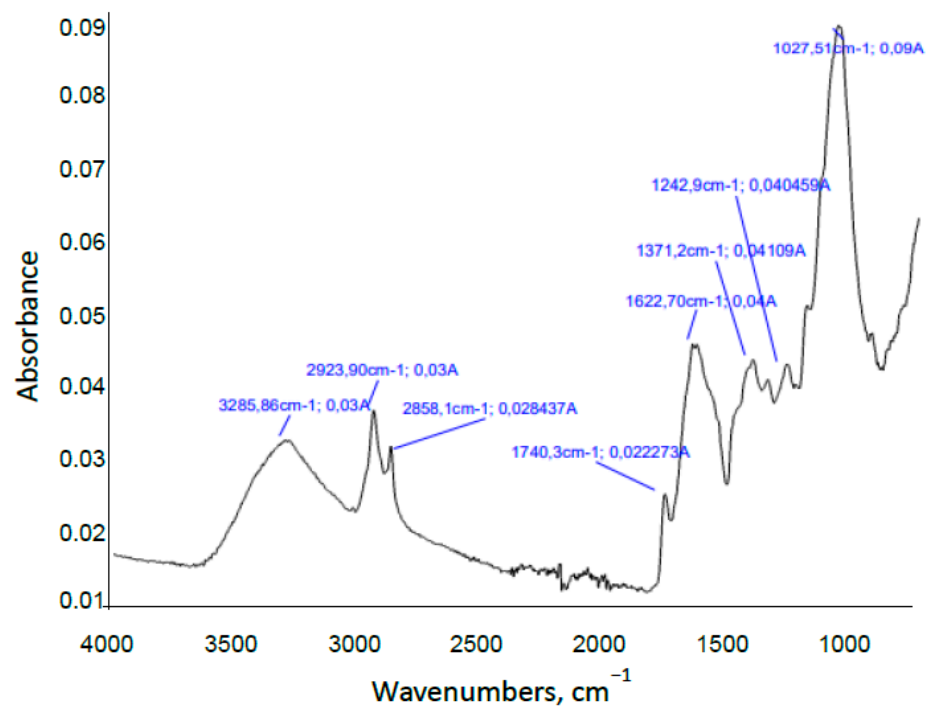

(a)

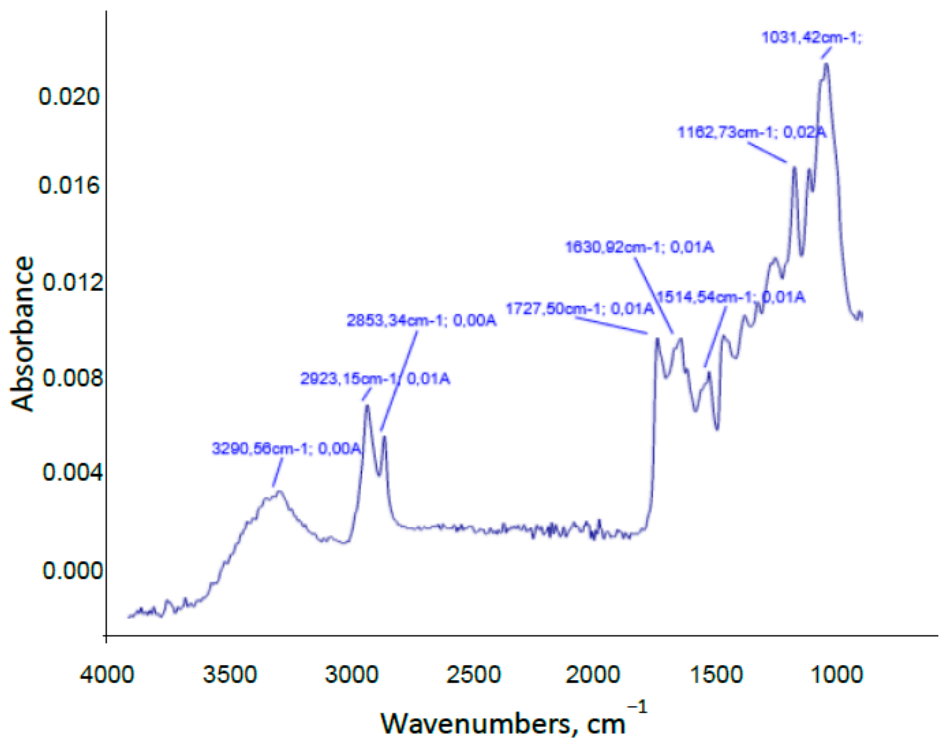

(b)

Figure 3. (a) FTIR spectra of raw material; (b) Insoluble solid resulting from liquid hot water pretreatment performed at $180{ }^{\circ} \mathrm{C}$ during $40 \mathrm{~min}$.

\subsection{Performance of the Enzymatic Hydrolysis}

The accessibility of cellulose from the pretreated material to enzymatic attack is one of the most important variables to measure the effectiveness of liquid hot water pretreatment [78]. The results of the enzymatic hydrolysis were expressed in terms of "saccharification efficiency" in Figure 4. Saccharification efficiency was calculated according to the procedure described in Section 2.6. Data were calculated for total potential glucose and xylose, not only from cellulose and hemicellulose. In the conditions tested and focused on glucose, the percentages of SE were between $21.44 \%\left(150{ }^{\circ} \mathrm{C}\right.$ and $10 \mathrm{~min}$ ) and $60.62 \%\left(180^{\circ} \mathrm{C}\right.$ and $\left.40 \mathrm{~min}\right)$. The comparison of these results with that obtained on the raw material without pretreatment $(20.3 \%)$ indicates that the pretreatment considerably improves the accessibility of enzymes to the pretreated material for breaking the complex polysaccharides, especially if pretreatment is performed at the highest temperature and residence time. Similar results have been reported by other researchers in their published studies $[39,50]$. Regarding the effect 
of residence time in the $\mathrm{SE}$, at $150{ }^{\circ} \mathrm{C}$, values changed from $21.44 \%$ (10 $\mathrm{min}$ ) to $29.44 \%$ (40 $\mathrm{min}$ ). At temperatures of $165^{\circ} \mathrm{C}$ and $180^{\circ} \mathrm{C}$, a similar effect was observed, with values that increased from $29.79 \%$ and $42.14 \%$ (10 $\mathrm{min}$ ) to $35.03 \%$ and $60.62 \%$ (40 $\mathrm{min}$ ), respectively.

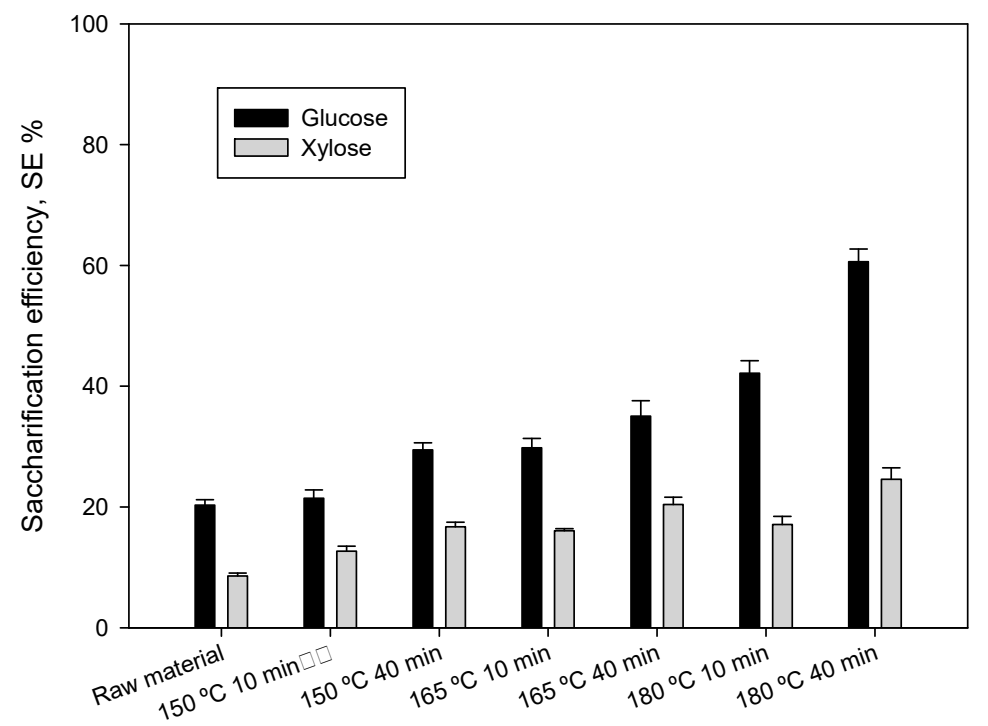

Figure 4. Saccharification efficiency (SE, \%) of enzymatic hydrolysis performed with raw material and pretreated materials at different operating conditions. Data were calculated for total potential glucose and xylose.

\subsection{Global Efficiency of a Two-step Process of Pretreatment and Consecutive Enzymatic Hydrolysis}

Table 2 shows a comparison between proposed process based on only one-step enzymatic hydrolysis and two-step pretreatment (in the different experimental conditions) and consecutive enzymatic hydrolysis. The severity factor $\left(\mathrm{R}_{0}\right)$ indicates the severity of the pretreatment [79-81]. The equation to determine the severity factor that involves the reaction time and temperature is the following:

$$
\mathrm{R}_{0}=t \times e^{\frac{\left(\mathrm{T}-\mathrm{T}_{\mathrm{ref}}\right)}{14.75}}
$$

where $t$ is the residence time $(\min )$; $T$ is the temperature $\left({ }^{\circ} \mathrm{C}\right)$; and $T_{\text {ref }}$ is the reference temperature, usually set to $100{ }^{\circ} \mathrm{C}$ [82].

The global efficiency values were very similar to the saccharification efficiency in many of the tested conditions according to the glucose recovery in IS analysis, where low solubilization of this component in the liquid fraction after pretreatment was found.

Regarding the overall glucose efficiency, experimental values obtained ranged between $17.20 \%$ and $61.02 \%$ of the potential glucose of the raw material. With regard to the $61.02 \%$ value, the majority of glucose came from the enzymatic hydrolysis stage, since during the pretreatment, only $14 \%$ of the glucose contained in the raw material was solubilized in the liquid fraction. From the data obtained, it can be concluded that, in order to reach high global glucose efficiency, a temperature of $180{ }^{\circ} \mathrm{C}$ and a medium residence time of $40 \mathrm{~min}$ should be chosen. 
The global efficiency of xylose followed a similar pattern to that of pretreatment (xylose recovery evaluated in the liquid fraction), due to the low amount of xylose released in the enzymatic hydrolysis step. The highest efficiency was obtained also at $180^{\circ} \mathrm{C}$ and $40 \mathrm{~min}$ of residence time, as for glucose. The global efficiency ranged from $8.58 \%$ for enzymatic hydrolysis without any previous pretreatment to $26.12 \%$ for a two-step process including a liquid hot water pretreatment at $180^{\circ} \mathrm{C}$ for $40 \mathrm{~min}$ and an enzymatic hydrolysis.

The above results of global efficiency of a two-step process involving pretreatment and consecutive enzymatic hydrolysis are reasonable for the sugar yield (60-70\%), according to Kumar et al. [83]. Generally, our global efficiencies are in the (slightly lower) range of other studies found in the literature that were performed with different biomass materials. For example, Imman et al. [84] reported $82 \%$ of glucose yield for corncobs pretreated at $160^{\circ} \mathrm{C}$ for $10 \mathrm{~min}$. Pérez et al. [37] found $38 \%$ of xylose yield for wheat straw pretreated at $188^{\circ} \mathrm{C}$ for $40 \mathrm{~min}$.

A correlation between the severity factor and glucose and xylose global efficiencies was not observed. A larger influence of temperature than time of pretreatment seems to occur.

The possible formation of fermentation inhibitors, particularly phenolic compounds, was investigated by analyzing the liquid fractions. Table 2 also reports the values of total polyphenol content in the different liquid fractions (only the liquid fractions obtained from the enzymatic hydrolysis of solid samples subjected or not to liquid hot water pretreatment). Liquid hot water pretreatment has been mainly used to extract phenolic compounds from many different sources, such as plants and food-industry byproducts [85-89]. In many of these studies, the total phenolic compounds and the total antioxidant capacity were measured. A higher total phenolic compound concentration and a higher antioxidant activity were observed in the extracts obtained at higher temperatures and at longer extraction times. This could explain that, when the pretreatment was performed, the phenolic compounds were released, and then, in the liquid fraction derived from enzymatic hydrolysis, they are in a lower concentration.

Particularly, phenolic compound concentrations are quite below concentrations that inhibit sugar fermentation. This agrees with the review performed by Jönsson and Martín [40] on pretreatment of lignocellulose. These authors reported that hydrothermal processing minimized the formation of fermentation inhibitors and particularly phenolic compounds. With regard to concentrations to get an inhibitory impact, Fosso-Kankeu et al. [90] found that the inhibitory effect of phenols on the viability of Saccharomyces cerevisiae, and therefore on ethanol productivity, was not significant at concentrations of $2000 \mathrm{mg} / \mathrm{L}$ of vanillin. Yeast was able to adapt to a medium with this concentration of vanillin. Instead, they found total inhibition of bioethanol production when working with a vanillin concentration of $4000 \mathrm{mg} / \mathrm{L}$. In addition, Allard-Massicotte et al. [91], in their study about phenols removal from pre-hydrolysate by laccase, reported that a phenolic compounds concentration of $280 \mathrm{mg} / \mathrm{L}$ was far below the limit of inhibition in the acetone-butanol-ethanol fermentation.

Finally, Table 3 shows the analysis of variance, two-way ANOVA test, used to simultaneously evaluate the effect of time and temperature on global efficiency (glucose and xylose, \%) and phenolic compounds concentration. The results indicated that the global efficiency in the range studied was significantly $(p<0.05)$ affected by the two factors, time and temperature. However, there was no difference in the means of both factors, temperature and time, when phenolic compounds concentration was evaluated. Also, there is no indication of important differences in the data of different blocks or replicates at the $5.0 \%$ significance level. 
Table 2. Global efficiency of one- and two-step hydrolyses (data were calculated for total glucose and xylose) and phenolic compounds concentration on liquid fractions.

\begin{tabular}{|c|c|c|c|c|c|c|c|}
\hline & \multicolumn{7}{|c|}{ Process } \\
\hline & \multirow{2}{*}{ No Pretreatment } & \multicolumn{2}{|c|}{$150^{\circ} \mathrm{C}$} & \multicolumn{2}{|c|}{$165^{\circ} \mathrm{C}$} & \multicolumn{2}{|c|}{$180^{\circ} \mathrm{C}$} \\
\hline & & $10 \mathrm{~min}$ & $40 \mathrm{~min}$ & $10 \mathrm{~min}$ & $40 \mathrm{~min}$ & $10 \mathrm{~min}$ & $40 \mathrm{~min}$ \\
\hline $\log R_{0}$ & - & 2.5 & 2.9 & 3.4 & 3.1 & 3.5 & 4.0 \\
\hline Glucose, \% & $20.30 \pm 1.08^{B}$ & $17.20 \pm 1.68^{\mathrm{A}}$ & $27.86 \pm 0.76^{\mathrm{D}}$ & $24.75 \pm 2.56^{\mathrm{C}}$ & $45.84 \pm 0.90^{\mathrm{F}}$ & $34.56 \pm 0.52^{\mathrm{E}}$ & $61.02 \pm 1.75^{\mathrm{C}}$ \\
\hline Xylose, $\%$ & $8.58 \pm 0.42^{\mathrm{A}}$ & $8.60 \pm 0.51^{\mathrm{A}}$ & $13.94 \pm 1.49^{B}$ & $12.89 \pm 0.91^{\mathrm{B}}$ & $19.03 \pm 0.76^{C}$ & $13.64 \pm 0.50^{\mathrm{B}}$ & $26.12 \pm 1.01^{\mathrm{D}}$ \\
\hline $\begin{array}{l}\text { Phenolic compounds } \\
\text { concentration, } \mathrm{mg} / \mathrm{L}\end{array}$ & $605.57 \pm 29.40^{\mathrm{E}}$ & $72.24 \pm 6.51 \mathrm{AB}$ & $80.36 \pm 3.16^{\mathrm{D}}$ & $79.81 \pm 6.24^{\mathrm{D}}$ & $77.44 \pm 9.00 \mathrm{CD}$ & $75.58 \pm 2.05^{B C}$ & $69.12 \pm 9.41^{A}$ \\
\hline
\end{tabular}

Table 3. Analysis of variance (ANOVA) for the comparison of differences between means.

\begin{tabular}{|c|c|c|c|c|c|c|}
\hline Dependent Variable & Source & Type III Sum of Squares & Df & Mean Square & F-Ratio & $p$-Value \\
\hline \multirow{6}{*}{ Glucose, \% } & Main effects & & & & & \\
\hline & Temperature & 1914.2 & 1 & 1914.2 & 126.89 & 0.0000 \\
\hline & Time & 1694.4 & 1 & 1694.4 & 112.32 & 0.0000 \\
\hline & Blocks-replicates & 5.77951 & 2 & 2.88976 & 0.19 & 0.8280 \\
\hline & Total error & 196.115 & 13 & 15.0858 & & \\
\hline & Total (corrected) & 3810.28 & 17 & & & \\
\hline \multirow{6}{*}{ Xylose, \% } & Main effects & & & & & \\
\hline & Temperature & 222.396 & 1 & 222.396 & 57.92 & 0.0000 \\
\hline & Time & 287.041 & 1 & 287.041 & 78.65 & 0.0000 \\
\hline & Blocks-replicates & 1.77303 & 2 & 0.886517 & 0.23 & 0.7970 \\
\hline & Total error & 49.9145 & 13 & 3.83957 & & \\
\hline & Total (corrected) & 561.125 & 17 & & & \\
\hline \multirow{6}{*}{$\begin{array}{l}\text { Phenolic compounds } \\
\text { concentration, mg/L }\end{array}$} & Main effects & & & & & \\
\hline & Temperature & 59.4075 & 1 & 59.4075 & 3.34 & 0.0905 \\
\hline & Time & 1.46205 & 1 & 1.46205 & 0.08 & 0.7787 \\
\hline & Blocks-replicates & 30.4436 & 2 & 15.2218 & 0.86 & 0.4471 \\
\hline & Total error & 230.943 & 13 & 17.7649 & & \\
\hline & Total (corrected) & 327.256 & 17 & & & \\
\hline
\end{tabular}




\section{Conclusions}

Liquid hot water pretreatment is a promising and environmentally friendly procedure to improve enzymatic hydrolysis of a very common vegetable waste, Italian green pepper, to produce fermentable sugars. An increase in temperature and contact time during pretreatment produced a positive effect on glucose recovery. Particularly, the incorporation of the liquid hot water step at $180^{\circ} \mathrm{C}$ for $40 \mathrm{~min}$ before enzymatic hydrolysis resulted in a three-fold increase in glucose (from $20.3 \%$ to $61.0 \%$ ) and xylose (from $8.6 \%$ to $26.1 \%$ ) yields. Concentrations of phenolic compounds were very low to inhibit later sugar fermentation.

Numerous researchers are currently working with lignocellulosic biomass, especially agricultural byproducts and wastes, because they are abundant, inexpensive, sustainable, and biodegradable. Italian green pepper is very commonly used in Mediterranean cooking, and, as such, waste levels of this food are significantly high. We believe that the enormous quantity of this food being discarded annually should encourage looking into alternative treatments to maximize the value of this interesting feedstock.

Supplementary Materials: The following are available online at http://www.mdpi.com/2304-8158/9/11/1640/s1.

Author Contributions: Conceptualization, M.A.M.-L. and A.P.; Formal analysis, M.A.M.-L. and L.C.-R.; Funding acquisition, M.C.; Investigation, M.A.M.-L., L.C.-R., A.P. and G.B.; Methodology, M.A.M.-L. and A.P.; Resources, G.B.; Software, M.A.M.-L. and M.C.; Writing-original draft, M.A.M.-L.; Writing-review and editing, M.A.M.-L. and G.G.-G. All authors have read and agreed to the published version of the manuscript.

Funding: This research received no external funding.

Conflicts of Interest: The authors declare no conflict of interest.

\section{References}

1. FAO. Global Food Losses and Food Waste_Extent, Causes and Prevention; FAO: Rome, Italy, 2011.

2. Albergamo, A.; Costa, R.; Bartolomeo, G.; Rando, R.; Vadalà, R.; Nava, V.; Gervasi, T.; Toscano, G.; Germanò, M.P.; D'Angelo, V.; et al. Grape water: Reclaim and valorization of a by-product from the industrial cryoconcentration of grape (Vitis vinifera) must. J. Sci. Food Agric. 2020, 100, 2971-2981. [CrossRef]

3. Albergamo, A.; Salvo, A.; Carabetta, S.; Arrigo, S.; Di Sanzo, R.; Costa, R.; Dugo, G.; Russo, M. Development of an antioxidant formula based on peanut by-products and effects on sensory properties and aroma stability of fortified peanut snacks during storage. J. Sci. Food Agric. 2020. [CrossRef]

4. Eurostat. The Fruit and Vegetable Sector in the EU-A Statistical Overview; Eurostat: Luxembourg, 2015.

5. Krauß, S.; Vetter, W. Stable carbon and nitrogen isotope ratios of red bell pepper samples from Germany, The Netherlands, and Spain. J. Agric. Food Chem. 2019, 67, 4054-4063. [CrossRef] [PubMed]

6. Statistica. Available online: https://es.statista.com/estadisticas/529468/producciones-de-pimientos-frescosen-el-mundo (accessed on 12 August 2020).

7. Food and Agriculture Organization of the United Nations. Available online: http://www.fao.org/faostat/en/ \#data/QC (accessed on 12 August 2020).

8. Statistics from Ministry of Agriculture, Fisheries and Food (Spain). Available online: https://www.mapa.gob. es/es/estadistica/temas/default.aspx (accessed on 12 August 2020).

9. National Institute of Statistics-Agriculture and the Environment (Spain). Available online: http://www.ine. es/dyngs/INEbase/es/categoria.htm?c=Estadistica_P\&cid=1254735727106 (accessed on 12 August 2020).

10. FEPEX, Spanish Federation of Associations of Exporting Producers of Fruits, Vegetables, Flowers and Live Plants. Available online: https://www.fepex.es/inicio.aspx (accessed on 12 August 2020).

11. EUROSTAT. Available online: https://ec.europa.eu/eurostat/data/database (accessed on 12 August 2020).

12. FRUITLOGISTICA. European Statistics Handbook. Available online: https://www.fruitlogistica.de/media/fl/ fl_dl_all/auf_einen_blick/European_Statistics_Handbook_2019.pdf (accessed on 12 August 2020).

13. Díaz, A.I.; Laca, A.; Laca, A.; Díaz, M. Treatment of supermarket vegetable wastes to be used as alternative substrates in bioprocesses. Waste Manag. 2017, 67, 59-66. [CrossRef] [PubMed]

14. Cabrera, E.; Muñoz, M.J.; Martín, R.; Caro, I.; Curbelo, C.; Díaz, A.B. Alkaline and alkaline peroxide pretreatments at mild temperature to enhance enzymatic hydrolysis of rice hulls and straw. Bioresour. Technol. 2014, 167, 1-7. [CrossRef] [PubMed] 
15. Hassan, S.S.; Williams, G.A.; Jaiswal, A.K. Emerging technologies for the pretreatment of lignocellulosic biomass. Bioresour. Technol. 2018, 262, 310-318. [CrossRef]

16. Intanakul, P.; Krairiksh, M.; Kitchaiya, P. Enhancement of enzymatic hydrolysis of lignocellulosic wastes by microwave pretreatment under atmospheric pressure. J. Wood Chem. Technol. 2003, 23, 217-225. [CrossRef]

17. Loow, Y.L.; New, E.K.; Yang, G.H.; Ang, L.Y.; Foo, L.Y.W.; Wu, T.Y. Potential use of deep eutectic solvents to facilitate lignocellulosic biomass utilization and conversion. Cellulose 2017, 24, 3591-3618. [CrossRef]

18. Sarkar, N.; Ghosh, S.K.; Bannerjee, S.; Aikat, K. Bioethanol production from agricultural wastes: An overview. Renew. Energy 2012, 37, 19-27. [CrossRef]

19. Sun, Y.; Cheng, J. Hydrolysis of lignocellulosic materials for ethanol production: A review. Bioresour. Technol. 2002, 83, 1-11. [CrossRef]

20. Talebnia, F.; Karakashev, D.; Angelidaki, I. Production of bioethanol from wheat straw: An overview on pretreatment, hydrolysis and fermentation. Bioresour. Technol. 2010, 101, 4744-4753. [CrossRef] [PubMed]

21. Wan, C.; Zhou, Y.; Li, Y. Liquid hot water and alkaline pretreatment of soybean straw for improving cellulose digestibility. Bioresour. Technol. 2011, 102, 6254-6259. [CrossRef] [PubMed]

22. Yu, Q.; Zhuang, X.; Yuan, Z.; Wang, Q.; Qi, W.; Wang, W.; Zhang, Y.; Xu, J.; Xu, H. Two-step liquid hot water pretreatment of Eucalyptus grandis to enhance sugar recovery and enzymatic digestibility of cellulose. Bioresour. Technol. 2010, 101, 4895-4899. [CrossRef] [PubMed]

23. Panahi, H.K.S.; Dehhaghi, M.; Aghbashlo, M.; Karimi, K.; Tabatabaei, M. Conversion of residues from agro-food industry into bioethanol in Iran: An under-valued biofuel additive to phase out MTBE in gasoline. Renew. Energy 2020, 145, 699-710. [CrossRef]

24. Arshadi, M.; Attard, T.M.; Lukasik, R.M.; Brncic, M.; da Costa Lopes, A.M.; Finell, M.; Geladi, P.; Gerschenson, L.N.; Gogus, F.; Herrero, M.; et al. Pretreatment and extraction techniques for recovery of added value compounds from wastes throughout the agri-food chain. Green Chem. 2016, 18, 6160-6204. [CrossRef]

25. Del Campo, I.; Alegría, I.; Zazpe, M.; Echeverría, M.; Echeverría, I. Diluted acid hydrolysis pretreatment of agri-food wastes for bioethanol production. Ind. Crops Prod. 2006, 24, 214-221. [CrossRef]

26. Khandaker, M.M.; Qiamuddin, K.; Majrashi, A.; Dalorima, T.; Hailmi, M.S.; Sharif Hossain, A.B.M. Bio-ethanol production from fruit and vegetable waste by using saccharomyces cerevisiae. Biosci. Res. 2018, 15, 1703-1711.

27. Morais, A.R.C.; Mata, A.C.; Bogel-Lukasik, R. Integrated conversion of agroindustrial residue with high pressure CO2 within the biorefinery concept. Green Chem. 2014, 16, 4312-4322. [CrossRef]

28. Morais, A.R.C.; Da Costa Lopes, A.M.; Bogel-Łukasik, R. Carbon dioxide in biomass processing: Contributions to the green biorefinery concept. Chem. Rev. 2015, 115, 3-27. [CrossRef]

29. Polanowska, K.; Nowak, J.; Łukasik, R.M. Efficient extraction of vicine from faba beans using reactive system of high-pressure CO2/water. J. CO2 Util. 2019, 33, 473-477. [CrossRef]

30. Özbek, H.N.; Fockink, D.H.; Yanık, D.K.; Göğüş, F.; Lukasik, R. The green biorefinery concept for the valorisation of pistachio shell by high-pressure $\mathrm{CO} 2 / \mathrm{H} 2 \mathrm{O}$ system. J. Clean. Prod. 2018, 196, 842-851. [CrossRef]

31. Ao, T.; Luo, Y.; Chen, Y.; Cao, Q.; Liu, X.; Li, D. Towards zero waste: A valorization route of washing separation and liquid hot water consecutive pretreatment to achieve solid vinasse based biorefinery. J. Clean. Prod. 2020, 248, 119253. [CrossRef]

32. Ballesteros, I.; Oliva, J.M.; Negro, M.J.; Manzanares, P.; Ballesteros, M. Ethanol production from olive oil extraction residue pretreated with hot water. Applied Biochemistry and Biotechnology; Springer: Berlin/Heidelberg, Germany, 2002; Volume 98-100, pp. 717-732.

33. Chu, Q.; Song, K.; Hu, J.; Bu, Q.; Zhang, X.; Chen, X. Integrated process for the coproduction of fermentable sugars and lignin adsorbents from hardwood. Bioresour. Technol. 2019, 289, 121659. [CrossRef] [PubMed]

34. Kim, Y.; Hendrickson, R.; Mosier, N.S.; Ladisch, M.R. Liquid hot water pretreatment of cellulosic biomass. Methods Mol. Biol. 2009, 581, 93-102.

35. Li, M.; Cao, S.; Meng, X.; Studer, M.; Wyman, C.E.; Ragauskas, A.J.; Pu, Y. The effect of liquid hot water pretreatment on the chemical-structural alteration and the reduced recalcitrance in poplar. Biotechnol. Biofuels 2017, 10, 237. [CrossRef] 
36. Manzanares, P.; Ballesteros, I.; Negro, M.J.; González, A.; Oliva, J.M.; Ballesteros, M. Processing of extracted olive oil pomace residue by hydrothermal or dilute acid pretreatment and enzymatic hydrolysis in a biorefinery context. Renew. Energy 2020, 145, 1235-1245. [CrossRef]

37. Pérez, J.A.; Ballesteros, I.; Ballesteros, M.; Sáez, F.; Negro, M.J.; Manzanares, P. Optimizing Liquid Hot Water pretreatment conditions to enhance sugar recovery from wheat straw for fuel-ethanol production. Fuel 2008, 87, 3640-3647. [CrossRef]

38. Tian, D.; Shen, F.; Yang, G.; Deng, S.; Long, L.; He, J.; Zhang, J.; Huang, C.; Luo, L. Liquid hot water extraction followed by mechanical extrusion as a chemical-free pretreatment approach for cellulosic ethanol production from rigid hardwood. Fuel 2019, 252, 589-597. [CrossRef]

39. Zhuang, X.; Wang, W.; Yu, Q.; Qi, W.; Wang, Q.; Tan, X.; Zhou, G.; Yuan, Z. Liquid hot water pretreatment of lignocellulosic biomass for bioethanol production accompanying with high valuable products. Bioresour. Technol. 2016, 199, 68-75. [CrossRef]

40. Jönsson, L.J.; Martín, C. Pretreatment of lignocellulose: Formation of inhibitory by-products and strategies for minimizing their effects. Bioresour. Technol. 2016, 199, 103-112. [CrossRef]

41. Wells, J.M.; Drielak, E.; Surendra, K.C.; Kumar Khanal, S. Hot water pretreatment of lignocellulosic biomass: Modeling the effects of temperature, enzyme and biomass loadings on sugar yield. Bioresour. Technol. 2020, 300, 122593. [CrossRef] [PubMed]

42. ASTM D1106-96:2013. Standard Test Method for Acid-Insoluble Lignin in Wood; ASTM International: West Conshohocken, PA, USA, 2013.

43. Wise, L.E.; Murphy, M.; D'Addieco, A. Chlorite holocellulose, its fractionation and bearing on summative wood analysis and on studies on the hemicelluloses. Pap. Trade J. 1946, 122, 35-43.

44. ASTM D1103-60:1977. Withdrawn Standard: Method of Test for Alpha-Cellulose in Wood (Withdrawn 1985); ASTM International: West Conshohocken, PA, USA, 1977.

45. ASTM D1107-96:2013. Standard Test Method for Ethanol-Toluene Solubility of Wood; ASTM International: West Conshohocken, PA, USA, 2013.

46. ISO 18123:2015. Solid Biofuels-Determination of the Content of Volatile Matter; ASTM International: West Conshohocken, PA, USA, 2015.

47. ISO 18122:2015. Solid Biofuels-Determination of Ash Content; ASTM International: West Conshohocken, PA, USA, 2015.

48. ISO 18134-1:2015. Solid Biofuels—Determination of Moisture Content. Oven Dry Method. Total Moisture. Reference Method; ASTM International: West Conshohocken, PA, USA, 2015.

49. Jang, S.K.; Choi, J.H.; Kim, J.H.; Kim, H.; Jeong, H.; Choi, I.G. Statistical analysis of glucose production from Eucalyptus pellita with individual control of chemical constituents. Renew. Energy 2020, 148, 298-308. [CrossRef]

50. Binod, P.; Janu, K.U.; Sindhu, R.; Pandey, A. Chapter 10—Hydrolysis of lignocellulosic biomass for bioethanol production. Biofuels. Altern. Feedstocks Convers. Process. 2011, 229-250. [CrossRef]

51. Larnaudie, V.; Ferrari, M.D.; Lareo, C. Enzymatic hydrolysis of liquid hot water-pretreated switchgrass at high solid content. Energy Fuels 2019, 33, 4361-4368. [CrossRef]

52. Greenberg, A.E.; Clesceri, L.S.; Eaton, A. Standard Methods for the Examination of Water and Wastewater, APHA/AWWA/WEF, 22nd ed.; Cabs: Washington, DC, USA, 2005.

53. Quesada, L.; Pérez, A.; Calero, M.; Blázquez, G.; Martín-Lara, M.A. Kinetic study of thermal degradation of olive cake based on a scheme of fractionation and its behavior impregnated of metals. Bioresour. Technol. 2018, 261, 104-116. [CrossRef]

54. U.S. Department of Agriculture. Available online: https://fdc.nal.usda.gov/fdc-app.html\#/food-details/ 787811/nutrients (accessed on 12 August 2020).

55. Callejón-Ferre, A.J.; Carreño-Sánchez, J.; Suárez-Medina, F.J.; Pérez-Alonso, J.; Velázquez-Martí, B. Prediction models for higher heating value based on the structural analysis of the biomass of plant remains from the greenhouses of Almería (Spain). Fuel 2014, 116, 377-387. [CrossRef]

56. Szymańska-Chargot, M.; Chylińska, M.; Gdula, K.; Kozioł, A.; Zdunek, A. Isolation and characterization of cellulose from different fruit and vegetable pomaces. Polymers (Basel) 2017, 9, 495. [CrossRef]

57. Vinay, D. Nutritional evaluation of pea peel and pea peel extracted byproducts. Int. J. Food Sci. Nutr. 2018, 3, 65-67. 
58. Singh, A.; Kuila, A.; Adak, S.; Bishai, M.; Banerjee, R. Utilization of vegetable wastes for bioenergy generation. Agric. Res. 2012, 1, 213-222. [CrossRef]

59. Pinna-Hernández, M.G.; Martínez-Soler, I.; Díaz Villanueva, M.J.; Acien Fernández, F.G.; López, J.L.C. Selection of biomass supply for a gasification process in a solar thermal hybrid plant for the production of electricity. Ind. Crops Prod. 2019, 137, 339-346. [CrossRef]

60. Guil-Guerrero, J.L.; Martínez-Guirado, C.; Del Mar Rebolloso-Fuentes, M.; Carrique-Pérez, A. Nutrient composition and antioxidant activity of 10 pepper (Capsicum annuun) varieties. Eur. Food Res. Technol. 2006, 224, 1-9. [CrossRef]

61. Martín-Lara, M.A.; Ronda, A.; Zamora, M.C.; Calero, M. Torrefaction of olive tree pruning: Effect of operating conditions on solid product properties. Fuel 2017, 109-117. [CrossRef]

62. Vasco-Correa, J.; Shah, A. Techno-Economic bottlenecks of the fungal pretreatment of lignocellulosic biomass. Fermentation 2019, 5, 30. [CrossRef]

63. Gallina, G.; Cabeza, Á.; Grénman, H.; Biasi, P.; García-Serna, J.; Salmi, T. Hemicellulose extraction by hot pressurized water pretreatment at $160{ }^{\circ} \mathrm{C}$ for 19 different woods: Yield and molecular weight. J. Supercrit. Fluids 2018, 133, 716-725. [CrossRef]

64. Mok, W.S.L.; Antal, M.J. Uncatalyzed solvolysis of whole biomass hemicellulose by hot compressed liquid water. Ind. Eng. Chem. Res. 1992, 31, 1157-1161. [CrossRef]

65. Xu, Y.; Wang, P.; Xue, S.; Kong, F.; Ren, H.; Zhai, H. Green biorefinery-The ultra-high hydrolysis rate and behavior of Populus tomentosa hemicellulose autohydrolysis under moderate subcritical water conditions. RSC Adv. 2020, 10, 18908-18917. [CrossRef]

66. Momayez, F.; Karimi, K.; Horváth, I.S. Sustainable and efficient sugar production from wheat straw by pretreatment with biogas digestate. RSC Adv. 2019, 9, 27692-27701. [CrossRef]

67. Ko, J.K.; Kim, Y.; Ximenes, E.; Ladisch, M.R. Effect of liquid hot water pretreatment severity on properties of hardwood lignin and enzymatic hydrolysis of cellulose. Biotechnol. Bioeng. 2015, 112, 252-262. [CrossRef]

68. Hongdan, Z.; Shaohua, X.; Shubin, W. Enhacement of enzymatic saccharification of sugarcane bagasse by liquid hot wáter pretreatment. Bioresour. Technol. 2013, 143, 391-396. [CrossRef]

69. Cara, C.; Romero, I.; Oliva, J.M.; Sáez, F.; Castro, E. Liquid Hot Water Pretreatment of Olive Tree Pruning Residues. In Applied Biochemistry and Biotechnology. ABAB Symposium; Mielenz, J.R., Klasson, K.T., Adney, W.S., McMillan, J.D., Eds.; Humana Press: Totowa, NJ, USA, 2007. [CrossRef]

70. Wang, X.-J.; Hsiao, K.-C. Sugar degradation during autoclaving: Effects of duration and solution volume on breakdown of glucose. Physiol. Plant. 1995, 94. [CrossRef]

71. Orozco, A.M.; Al-Muhtaseb, A.H.; Albadarin, A.B.; Rooney, D.; Walker, G.M.; Ahmad, M.N.M. Acid-catalyzed hydrolysis of cellulose and cellulosic waste using a microwave reactor system. RSC Adv. 2011, 1, 839-846. [CrossRef]

72. Huang, J.; He, C.; Wu, L.; Tong, H. Thermal degradation reaction mechanism of xylose: A DFT study. Chem. Phys. Lett. 2016, 658, 114-124. [CrossRef]

73. Nitsos, C.K.; Choli-Papadopoulou, T.; Matis, K.A.; Triantafyllidis, K.S. Optimization of hydrothermal pretreatment of hardwood and softwood lignocellulosic residues for selective hemicellulose recovery and improved cellulose enzymatic hydrolysis. ACS Sustain. Chem. Eng. 2016, 4, 4529-4544. [CrossRef]

74. Gullón, P.; González-Muñoz, M.J.; Parajó, J.C. Manufacture and prebiotic potential of oligosaccharides derived from industrial solid wastes. Bioresour. Technol. 2011, 102, 6112-6119. [CrossRef] [PubMed]

75. Adel, A.M.; El-Wahab, Z.H.A.; Ibrahim, A.A.; Al-Shemy, M.T. Characterization of microcrystalline cellulose prepared from lignocellulosic materials. Part I. Acid catalyzed hydrolysis. Bioresour. Technol. 2010, 101, 4446-4455. [CrossRef]

76. Yang, H.; Yan, R.; Chen, H.; Lee, D.H.; Zheng, C. Characteristics of hemicellulose, cellulose and lignin pyrolysis. Fuel 2007, 86, 1781-1788. [CrossRef]

77. Ázar, R.I.S.; Bordignon-Junior, E.; Laufer, C.; Specht, J.; Ferrier, D.; Kim, D. Effect of lignin content on cellulolytic saccharification of liquid hot water pretreated sugarcane bagasse. Molecules 2020, 25, 623. [CrossRef]

78. Lin, W.; Chen, D.; Yong, Q.; Huang, C.; Huang, S. Improving enzymatic hydrolysis of acid-pretreated bamboo residues using amphiphilic surfactant derived from dehydroabietic acid. Bioresour. Technol. 2019, 293, 122055. [CrossRef] 
79. Aguilar, D.L.; Rodríguez-Jasso, R.M.; Zanuso, E.; de Rodríguez, D.J.; Amaya-Delgado, L.; Sanchez, A.; Ruiz, H.A. Scale-up and evaluation of hydrothermal pretreatment in isothermal and non-isothermal regimen for bioethanol production using agave bagasse. Bioresour. Technol. 2018, 263, 112-119. [CrossRef]

80. Ra, C.H.; Choi, J.G.; Kang, C.-H.; Sunwoo, I.Y.; Jeong, G.-T.; Kim, S.-K. Thermal acid hydrolysis pretreatment, enzymatic saccharification and ethanol fermentation from red seaweed, Gracilaria Verrucosa. Microbiol. Biotechnol. Lett. 2015, 43, 9-15. [CrossRef]

81. Sukwong, P.; Sunwoo, I.Y.; Lee, M.J.; Ra, C.H.; Jeong, G.T.; Kim, S.K. Application of the severity factor and HMF removal of red macroalgae Gracilaria Verrucosa to production of bioethanol by Pichia Stipitis and Kluyveromyces Marxianus with adaptive evolution. Appl. Biochem. Biotechnol. 2019, 187, 1312-1327. [CrossRef] [PubMed]

82. Kumar, R.; Mago, G.; Balan, V.; Wyman, C.E. Physical and chemical characterizations of corn stover and poplar solids resulting from leading pretreatment technologies. Bioresour. Technol. 2009, 100, 3948-3962. [CrossRef] [PubMed]

83. Kumar, L.; Chandra, R.; Chung, P.A.; Saddler, J. Can the same steam pretreatment conditions be used for most softwoods to achieve good, enzymatic hydrolysis and sugar yields? Bioresour. Technol. 2010, 101, 7827-7833. [CrossRef] [PubMed]

84. Imman, S.; Laosiripojana, N.; Champreda, V. Effects of liquid hot water pretreatment on enzymatic hydrolysis and physicochemical changes of corncobs. Appl. Biochem. Biotechnol. 2017, 184, 1-12. [CrossRef]

85. Güçlü-Üstündağ, Ö.; Mazza, G. Effects of pressurized low polarity water extraction parameters on antioxidant properties and composition of cow cockle seed extracts. Plant Foods Hum. Nutr. 2009, 64, 32-38. [CrossRef]

86. Plaza, M.; Abrahamsson, V.; Turner, C. Extraction and neoformation of antioxidant compounds by pressurized hot water extraction from apple byproducts. J. Agric. Food Chem. 2013, 61, 5500-5510. [CrossRef]

87. Plaza, M.; Turner, C. Pressurized hot water extraction of bioactives. TrAC Trends Anal. Chem. 2015, 71, 39-54. [CrossRef]

88. Rajha, H.; Ziegler, W.; Louka, N.; Hobaika, Z.; Vorobiev, E.; Boechzelt, H.; Maroun, R. Effect of the drying process on the intensification of phenolic compounds recovery from grape pomace using accelerated solvent extraction. Int. J. Mol. Sci. 2014, 15, 18640-18658. [CrossRef]

89. Xu, H.; Wang, W.; Jiang, J.; Yuan, F.; Gao, Y. Subcritical water extraction and antioxidant activity evaluation with on-line HPLC-ABTS + assay of phenolic compounds from marigold (Tagetes erecta L.) flower residues. J. Food Sci. Technol. 2015, 52, 3803-3811. [CrossRef]

90. Fosso-Kankeu, E.; Marx, S.; Meyer, A. Simulated inhibitory effects of typical byproducts of biomass pretreatment process on the viability of Saccharomyces cerevisiae and bioethanol production yield. Afr. J. Biotechnol. 2015, 14, 2383-2394. [CrossRef]

91. Allard-Massicotte, R.; Chadjaa, H.; Marinova, M. Phenols removal from hemicelluloses pre-hydrolysate by laccase to improve butanol production. Fermentation 2017, 3, 31. [CrossRef]

Publisher's Note: MDPI stays neutral with regard to jurisdictional claims in published maps and institutional affiliations.

(C) 2020 by the authors. Licensee MDPI, Basel, Switzerland. This article is an open access article distributed under the terms and conditions of the Creative Commons Attribution (CC BY) license (http://creativecommons.org/licenses/by/4.0/). 